\title{
Survey of Ground-Dwelling Predaceous and Parasitic Arthropods in Cabbage Fields in Upstate New York ${ }^{1}$
}

\author{
A. M. SHELTON, J. T. ANDALORO, ${ }^{2}$ AND C. W. HOY \\ Department of Entomology, New York State Agricultural Experiment Station, Cornell University, Geneva, New York 14456
}

Environ. Entomol. 12: 1026-1030 (1983)

\begin{abstract}
During 1979 and 1981, populations of ground-dwelling predators and parasites in rcsearch and commercial cabbage fields in upstate New York were assessed by pitfall trapping to determine species composition, abundance, phenology, and the impact of insecticides on them. Staphylinidae, Phalangida, Carabidae, and Araneida were consistently the most abundant predaceous taxa. Carabids and Staphylinids together comprised 75.9 and $74.1 \%$ of all predaccous or parasitic insects in commercial fields during 1979 and 1981, respectively. One of the 32 species of Carabidae captured, Pterostichus melanarius (llliger), accounted for $>50 \%$ of the total number of Carabidae. Total number of predators and parasites tended to decline from July through September in both treated and untreated fields, but this decline was hastened by the use of broad-spectrum insecticides.
\end{abstract}

Ground-dwelling predators can be important control agents of insect pests of brassica crops. In studies conducted in England, Hughes (1959) concluded that two gencra of carabids (Bembidion and Trechus) destroyed $>90 \%$ of the cabbage maggot, Hylemya brassicae Bouche, eggs. In another study Wright ct al. (1960) demonstrated an inverse relationship between the number of ground predators and survival of cabbage maggots in brassica. Further studies by Coaker and Williams (1963) utilized precipitin tests to identify several carabid and staphylinid predators of the immature stages of the cabbage maggot. In Canada, Wisharf et al. (1956) reported carabids as the most abundant group of predators on cabbage maggot eggs, and within this group Bembidion quadrimaculatum oppositum Say and B. nitidum (Kby.) were the most important. Furthermore, a survival model developed by Mukerji (1971) for cabbage maggot indicated the importance of pupal parasitism by a staphylinid, Aleochara bilineata Gyll., as a stabilizing factor in maggot populations. Predation by ground-dwelling arthropods on other cabbage insect pests has been reported (Pimental 1961, Oatman and Platner 1969, Weires and Chiang 1973), but their importance in controlling pest populations has not becn established.

Because we lack information on existing natural control agents, present management of insect pests in most commercial cabbage fields in New York relies solely on the use of insecticides for pest suppression. However, this strategy can substantially reduce the effectiveness of predators and parasites on pests like cabbage maggots (Pitre and Chapman 1964, Coaker 1966, Chapman and Eckenrode 1973). Thereforc, a documentation of the ground-dwelling parasite-predator complex and its phenology in New York cabbage fields and information on the effects of insecticides on them is required for the implementation of sound control practices. This information is not currently available in the literature. In this study we surveyed this complex in several upstate New

'Approved by the Director, N.Y. State Agric. Exp. Stn. . for publication as Journal Paper No. 3438. Received for publication 13 May 1982: accepted 2 February 1983.

IPM Programs, Comell University, Geneva, NY 14456.
York cabbage fields to identify possible biological control agents, observe their phenology, and assess the impact of insecticides on them.

\section{Materials and Methods}

This survey was conducted in commercial and research cabbage fields in Ontario County, New York. Three 4- to 5-ha commercial fields and one 1-ha untreated research field were surveyed during the 1979 cropping season. Two of the commercial ficlds were divided in half, and each half received a different insecticide treatment regime, either based on the recommendations of Cornell's Processing Cabbage Integrated Pest Management (IPM) Program (side A) or the grower's judgment (side B). During 1981, one 2-ha commercial field was surveyed. This field was divided into thirds, each treated with a different insecticide regime based on a low, moderate, or high action threshold for lepidopterous pests. $A l l$ insecticide applications were recorded.

Arthropods were collected in pitfall traps $(450-\mathrm{ml}$ plastic cups) placed within the rows between cabbage plants. Traps were filled with a mixture of water, detergent, and alcohol. From 25 to 50 traps were placed in each field for 3- to 7-day intervals. Arthropods were identified and enumerated, and the data were summarized by field, date, and mean per trap per 3 days.

\section{Results and Discussion}

In the untreated field during 1979, the most abundant predator-parasite taxa were Staphylinidae (27.3\%), Phalangida (24.9\%). Araneida (14.5\%), and Carabidac $(12.5 \%)$, and together they comprised ca. $80 \%$ of predaceous or parasitic arthropods captured (Table 1). Carabidae and Staphylinidae together comprised $66 \%$ of the predaceous or parasitic insect complex. In the commercial fields for both years, these four taxa were again the most abundant. Staphylinidae and Carabidac together comprised 75.9 and $74.1 \%$ of the insect predatorparasite complex in commercial ficlds during 1979 and 1981, respectively (Fig. 1 and 2).

Thirty-two species of Carabidae were identified from fields sampled during the 2 test years. More than half 
Table 1. Taxonomic composition of predaceous and parasitic arthropods captured in pitfall traps in an untreated cabbage field, Geneva, N.Y., 1979

\begin{tabular}{|c|c|c|c|c|c|c|c|c|c|}
\hline \multirow{2}{*}{ Taxon } & \multicolumn{6}{|c|}{ Mean/trap per 3 days } & \multirow{2}{*}{ Season $(\bar{x})$} & \multirow{2}{*}{$\mathrm{SD}^{a}$} & \multirow{2}{*}{$\begin{array}{l}\text { \% Of total } \\
\text { captured }\end{array}$} \\
\hline & 20-23-VII & 6-VIII & 17-20-VIII & $5-8 \cdot I X$ & 18-21-IX & $19-22-X$ & & & \\
\hline \multicolumn{10}{|l|}{ Insects } \\
\hline Staphylinidae & 11.57 & 2.92 & 2.10 & 1.38 & 0.90 & 7.52 & 4.40 & 4.24 & 27.3 \\
\hline Carabidae & 0.84 & 2.20 & 1.93 & 4.21 & 1.03 & 1.83 & 2.01 & 1.20 & 12.5 \\
\hline Hymenoptera & 1.24 & 1.94 & 1.38 & 1.29 & 0.83 & 3.21 & 1.65 & 0.84 & 10.2 \\
\hline Coccinellidae & 0.55 & 2.46 & 0.99 & 0.21 & 0.03 & 0 & 0.71 & 0.94 & 4.4 \\
\hline Formicidae & 0.24 & 0.42 & 0.79 & 0.29 & 0.60 & 0.93 & 0.55 & 0.28 & 3.4 \\
\hline Syrphidae & 0.71 & 0.08 & 0.14 & 0 & 0 & 0.07 & 0.17 & 0.27 & 1.1 \\
\hline Pentatomidae & 0 & 0 & 0.27 & 0 & 0 & 0 & 0.05 & 0.11 & 0.3 \\
\hline Coleoptera & 0 & 0 & 0 & 0.13 & 0 & 0.03 & 0.03 & 0.05 & 0.2 \\
\hline Diptera & 0 & 0 & 0 & 0.08 & 0.03 & 0 & 0.02 & 0.03 & 0.1 \\
\hline Chrysopidae & 0 & 0 & 0 & 0.08 & 0 & 0 & 0.01 & 0.03 & 0.1 \\
\hline Dolichopodidae & 0.02 & 0.02 & 0 & 0 & 0 & 0 & 0.01 & 0.01 & 0.1 \\
\hline \multicolumn{10}{|l|}{ Other unthropods } \\
\hline Phalangida & 0.91 & 1.80 & 4.93 & 4.38 & 7.23 & 4.79 & 4.01 & 2.30 & 24.9 \\
\hline Arancida & 3.09 & 6.76 & 3.00 & 0.50 & 0.20 & 0.52 & 2.34 & 2.52 & 14.5 \\
\hline Chilopoda & 0.02 & 0.04 & 0.17 & 0.13 & 0.13 & 0.07 & 0.09 & 0.06 & 0.6 \\
\hline Acarina & 0.18 & 0.02 & 0 & 0.08 & 0 & 0 & 0.05 & 0.07 & 0.05 \\
\hline Total no. & 19.37 & 18.66 & 15.70 & 12.76 & 10.98 & 18.97 & 16.07 & 3.55 & 100 \\
\hline
\end{tabular}

aSD of 3-day means.

Table 2. Species composition of Carabidae captured in pitfall traps in cabbage fields, Geneva, N.Y., 1979, 1981 ${ }^{\circ}$

\begin{tabular}{|c|c|c|c|c|c|c|c|c|c|c|}
\hline \multirow{3}{*}{ Species } & \multicolumn{9}{|c|}{ Mean/traps per 3 days } & \multirow{3}{*}{$\begin{array}{l}\% \text { Of } \\
\text { total }\end{array}$} \\
\hline & \multicolumn{6}{|c|}{1979 Plots } & \multicolumn{3}{|c|}{1981 Plots } & \\
\hline & Untreated & I & IIA & IIB & IIIA & IIIB & A & B & C & \\
\hline Pterostichos melanarius (Illiger) & 0.71 & 0.14 & 0.15 & 0.28 & 3.27 & 5.60 & 0.22 & 1.20 & 0.84 & 51 \\
\hline Bembidion quadrimaculatum oppositum Say & 0.15 & 0.34 & 0.86 & 0.69 & 0.41 & 0.30 & 0.02 & 0.22 & 0.18 & 13 \\
\hline Trechus apicallis Motschulsky & 0.39 & 0.30 & 0.18 & 0.09 & 0.13 & 0.12 & 0.12 & 0.42 & 0.10 & 8 \\
\hline Stenolophus comma (F.) & 0.34 & 0.32 & 0.23 & 0.57 & 0.15 & 0.08 & 0.05 & 0.05 & 0.08 & 8 \\
\hline Harpalus penasylvanicus (DeGeer) & 0.01 & & 0.39 & 0.67 & 0.05 & 0.03 & 0.03 & 0.05 & 0.10 & 5 \\
\hline H. bicolor (F.) & 0.01 & & 0.33 & 0.44 & & & 0.01 & & & 3 \\
\hline Evarthrus sodalis LeConte & & & 0.21 & 0.33 & & & & & & 2 \\
\hline B. obtusum Serville & & 0.02 & & & 0.13 & 0.39 & & & & 2 \\
\hline P. lucublandus Say & & & 0.04 & 0.20 & & 0.03 & & & 0.02 & 1 \\
\hline H. affinis (Shrank) & 0.07 & & 0.15 & 0.03 & & & & & & 1 \\
\hline Agonum placidum (Say) & & 0.03 & 0.06 & 0.04 & 0.03 & & 0.03 & 0.02 & 0.05 & 1 \\
\hline
\end{tabular}

"2l other species, each comprising $<1 \%$ of the total number captured, are listed in the text.

Table 3. Mean number of predaceous and parasitic arthropods collected in pitfall traps in three sections of a commercial cabbage field, each treated with a different action threshold for Lepidoptera, Geneva, N.Y., $1981^{\circ}$

\begin{tabular}{lccc}
\hline \multirow{2}{*}{ Collection date } & \multicolumn{3}{c}{ Mean/trap per 3 days ${ }^{b}$} \\
\cline { 2 - 4 } & $\begin{array}{c}\text { Section A; } \\
\text { low threshold }\end{array}$ & $\begin{array}{c}\text { Section B; } \\
\text { high threshold }\end{array}$ & $\begin{array}{c}\text { Section C; } \\
\text { moderate threshold }\end{array}$ \\
\hline & & & \\
17-VIII & $4.87 \mathrm{~b}$ & $14.17 \mathrm{a}$ & $12.75 \mathrm{a}$ \\
$20-$ VIII & $3.50 \mathrm{~b}$ & $10.60 \mathrm{a}$ & $5.30 \mathrm{~b}$ \\
$24-$ VIII & $4.72 \mathrm{~b}$ & $6.52 \mathrm{a}$ & $2.32 \mathrm{c}$ \\
$4-I X$ & $2.97 \mathrm{ab}$ & $3.41 \mathrm{a}$ & $1.61 \mathrm{~b}$ \\
\hline
\end{tabular}

"Insecticide treatments are as follows. Section A-methamidophos, 10 August. Section B-permethrin, August. Section C--Bacillas tharingiensis, 6 August; methamidophos, 17 August (after that day's collection)

"Mean separation horizontal. Means followed by the same letter are not significantly different at the $5 \%$ level, by Waller and Duncan's BSD rute. of the Carabidae captured were Pterostichus melanarius (Illiger) (Table 2). Four carabid species, each comprising from 8 to $51 \%$ of the total number captured, were found in all fields surveyed during 1979 and 1981. Those species comprising $\leq 5 \%$ of the total Carabidae were not found in all fields, but in some fields were as abundant as the more common species. Twenty-one specics, each comprising $<1 \%$ of the total Carabidae captured and not included in Table 2, were: $P$. chalcites Say, Harpalus caliginosus (F.), H. plenalis Casey, Abacidus permundus Say, Chlaenius tricolor Dejean, C. emarginatus Say, Stenolophus ochropezus (Say), Agonum muelleri (Herbst), A. gratiosum Mannerheim, A. cupripenne Say, Anisodactylus sanctaecrucis (F.), Loricersa pilicornis (F.), Clivina impressifrons LeConte, Bembidion rapidum LeConte, B. gratiosum Casey, B. transversale Dejean, B. versicolor LeConte, Trechus discus (F.), Bradycellus rupestris (Say), B. neglectus LeConte, and Elaphropus anceps (LeConte). 


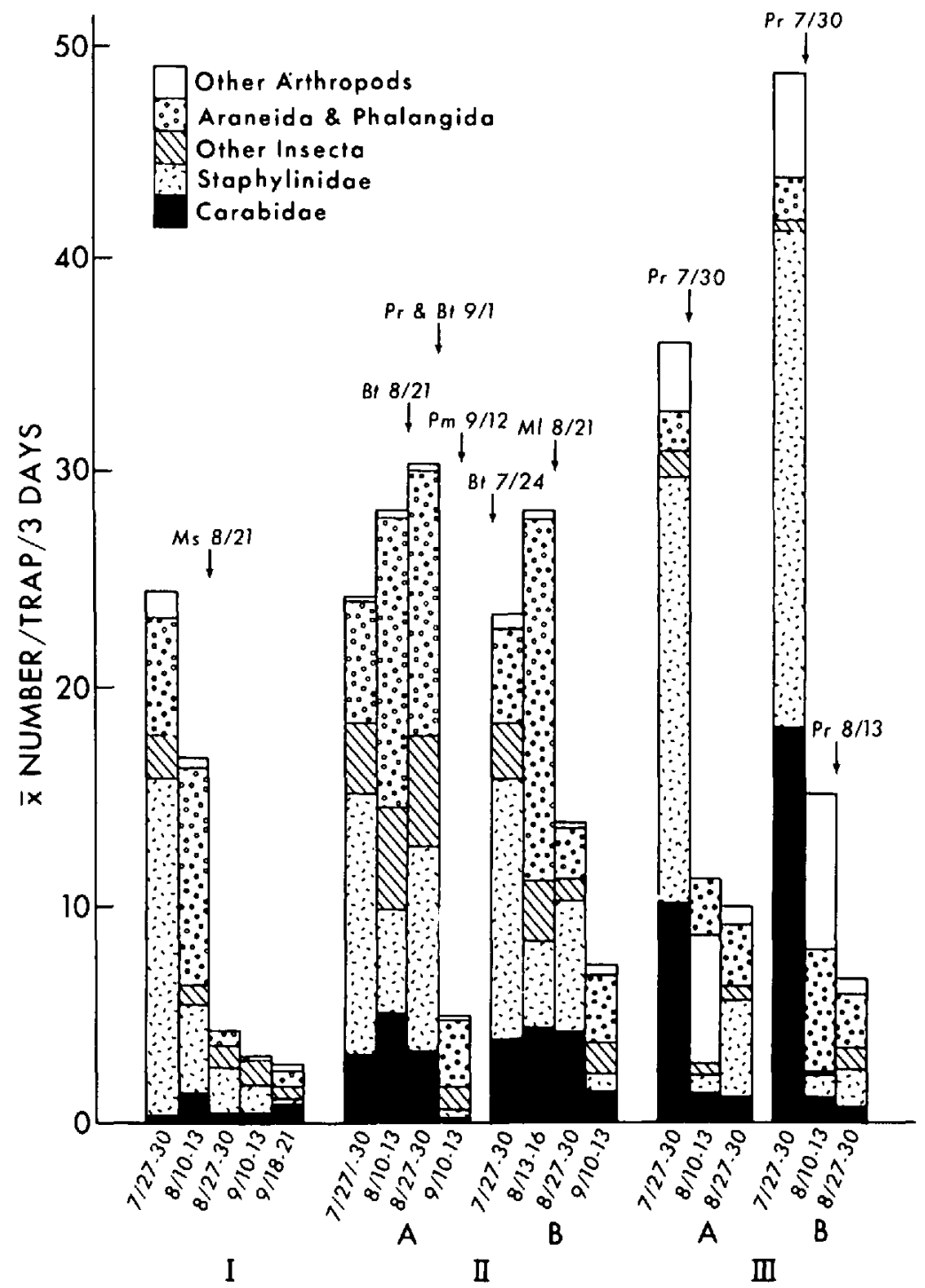

FIG. 1. Average number of predaceous and parasitic arthropods collected in pitfall traps in cabbage and the influence of insecticides. $(\mathrm{B}+=$ Bacillus thuringiensis, $\mathrm{Ml}=$ methomyl, $\mathrm{Ms}=$ methamidophos, $\mathrm{Pm}=$ permethrin, $\mathrm{Pr}=$ parathion), Ontario County, N.Y., 1979.

$P$. melanarius merits further study as a possible biological control agent. It was the most abundant Carabid in this study, and in a survey conducted by Rivard (1964a) on agricultural lands near Belleville, Ontario. $P$. melanarius has a high reproductive potential, compared with other Carabids, and the peak breeding period is from early August to late September (Rivard 1964b), a time when the cabbage pest complex is at its peak. However, during this period very few $P$. melanarius larvae were captured in this study, possibly because their behavior prevented them from being captured as easily as adults.

The total number of predators and parasites tended to decline from July through September in both treated and untreated fields (Table 1, Fig. 1 and 2). In the untreated field, Staphylinids decreased until October and then increased, whereas Phalangids increased until October and then decreased (Table 1). The total predator and parasite populations always remained between 19.4 and 11.0 per trap per 3 days, a maximum decline of $43 \%$. In the commercial fields sampled in 1979 (Fig. 1), observed population declines were more drastic (69 to $91 \%$ ), and followed the application of methamidophos, methomyl, or parathion. In the field sampled in 1981, a more rapid decline in total trap catches occurred in sections that were treated with methamidophos than in untreated sections. The mean number of predators and parasites per trap per 3 days on the first sample date in section $A$, treated with methamidophos on 10 August, was significantly lower than the mean in the other sections on the same date (Table 3). The means in sections $B$ and $C$ were not significantly different on 17 August. However, after the sample was collected on this date, section $\mathrm{C}$ was treated with methamidophos and the mean trap catch in section $\mathrm{C}$ was significantly lower than in section $\mathrm{B}$ on all subsequent sampling dates. 


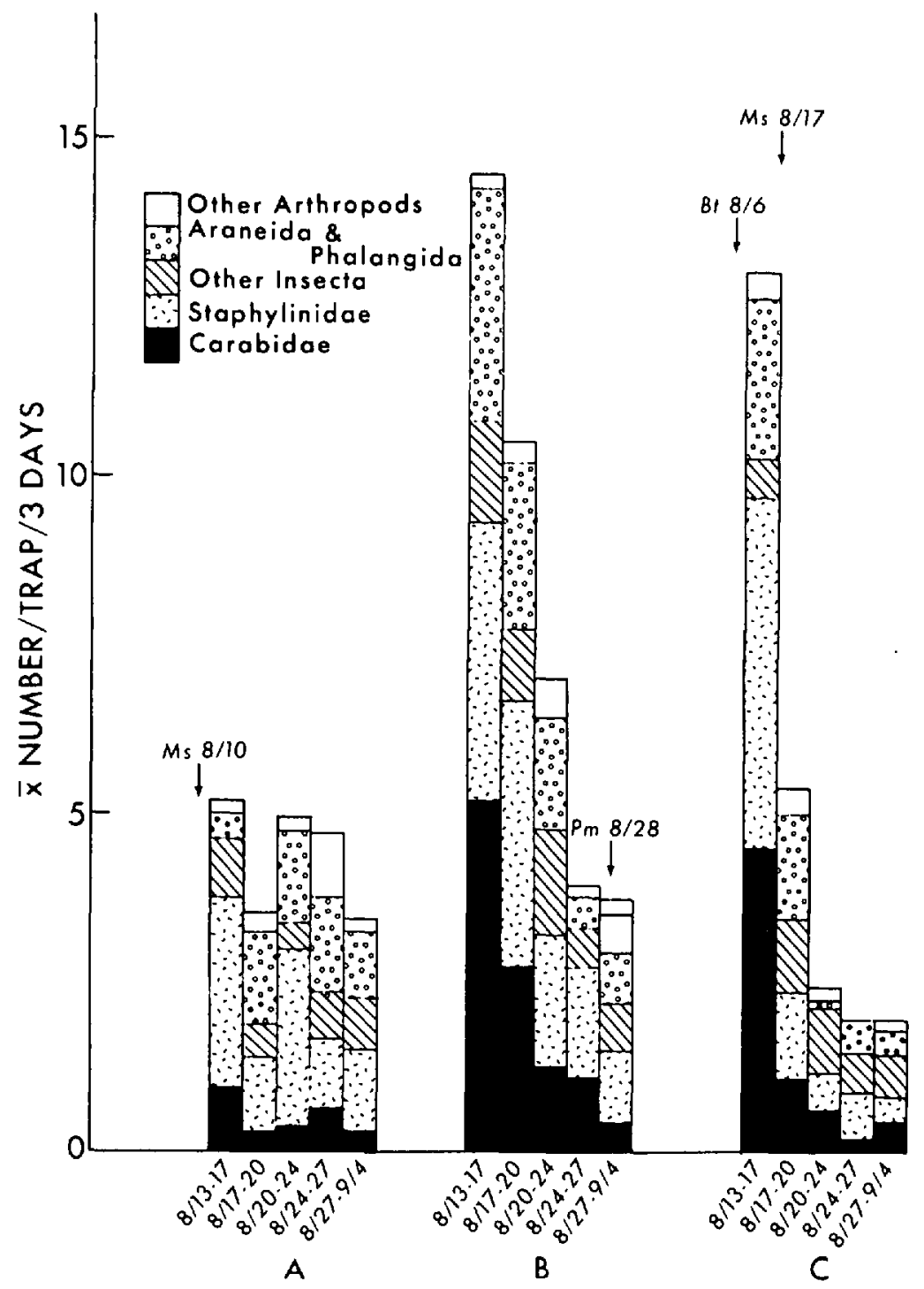

FIG. 2. Average number of predaceous and parasitic arthropods collected in pitfall traps in cabbage and the influence of insecticides $(\mathrm{B}+=$ Bacillus thuringiensis, $\mathrm{Pm}=$ permethrin, $\mathrm{Ms}=$ methamidophos $)$, Ontario County, N.Y., 1981 .

This study is the first documentation of the occurrence and abundance of predaccous and parasitic grounddwclling arthropods in cabbage fields in upstate New York and the effects of insecticides on their abundance. Sharp declines in abundance of these arthropods were observed after field application of some broad-spectrum insecticides to this agroecosystem. The actual importance of this decline depends on the extent of pest control which would have been exerted by this complex. As previously mentioned for other locations, the extent of control of cabbage maggot can be substantial, whereas the extent of control of the other members of the pest complex remains unanswered. However, because of the apparent deleterious effects of insecticides on these natural control agents and the ability of our major pests (Lepidoptera, onion thrips, and cabbage maggots) to im- migrate and rapidly colonize cabbage, it is likely that broad-spectrum chemical control in cabbage will give rise to a pest population temporarily free from many of these parasites and predators. Further studies identifying the proper timing, selection, and rates of insecticides needed to conserve our biological control agents are needed to develop sound pest management strategies on cabbage in our area.

\section{Acknowledgment}

We express thanks to $S$. Nichols (Carabidae) and R. Hoebeck for aid in taxonomy; B. Wilsey, K. Rose, and W. Lanterman for technical assistance; and the Cornell IPM Programs.

\section{REFERENCES CITED}

Chapman, R. K., and C. J. Eckenrode, 1973. Effect of 
insecticide placement on predator numbers and cabbage maggot control. J. Econ. Entomol. 66: 1153-1158.

Coaker, T. H. 1966. The effect of soil insecticides on the predators and parasites of the cabbage root fly (Erioischia brassicae (Bouche)) and on the subsequent damage caused by the pest. Ann. Appl. Biol. 57: 397-407.

Coaker, T. H., and D. A. Williams. 1963. The importance of some Carabidae and Staphylinidae as predators of the cabbage root fly, Erioischia brassicae (Bouche). Entomol. Exp. Appl. 6: 156-164.

Hughes, R. D. 1959. The natural mortality of Erioschia bras. sicae (Bouche) during the egg stage and the first generation. J. Anim. Ecol. 28: 343-357.

Mukerji, M. K. 1971. Major factors in survival of the immature stages of Hylemya brassicae (Diptera: Anthomyiidae) on cabbage. Can. Entomol. 103: 717-728.

Oatman, E. R., and G. R. Platner. 1969. An ecological study of insect populations on cabbage in Southern California. Hilgardia 40: $1-40$.

Pimental, D. 1961. Competition and the species-per-genus structure of communities. Ann. Entomol. Soc. Am. 54: 323-333.
Pitre, H. N., and R. K. Chapman. 1964. Ground beetles as predators of cabbage maggot eggs. N. Cent. Branch Entomol. Soc. Am. Proc. 19: 102-103.

Rivard, 1. 1964a. Carabid beetles (Coleoptera: Carabidae) from agricultural lands near Belleville, Ontario. Can. Entomol. 96: $517-520$.

1964b. Observations on the breeding periods of some ground beetles (Coleoptera: Carabidae) in Eastem Ontario. Can. J. Zool. 42: 1081-1084.

Weires, R. W., and H. C. Chiang. 1973. Integrated control prospects of major cabbage insect pests in Minnesotabased on the faunistic, host varietal, and trophic relationships. Univ. Minn. Agric. Exp. Stn. Tech. Bull. 291. 42 pp.

Wishart, G., J. F. Doane, and G. E. Maybee. 1956. Notes on beetles as predators of eggs of Hylema brassicae (Bouche) (Diptera: Anthomyiidae). Can. Entomol. 88: 634-639.

Wright, D. W., R. D. Hughes, and J. Worral. 1960. The effects of certain predators on the number of cabbage root fly $[($ Erioshia brassicae) (Bouche)] and the subsequent danage caused by the pest. Ann. Appl. Biol. 48: 756-763. 